\title{
THE CUSTOMS UNION IN THE CONTEXT OF EU-TURKEY RELATIONS: AN EVOLUATION OF CURRENT DEBATES
}

\section{E mirhan GÖRAL * M uzaffer DARTAN**}

"We are today witnessing an event of great political significance. Turkey is part of Europe. That is really the ultimate meaning of what we are doing today."

\section{Abstract}

With the Decision No 1/95, EC-Turkey Association Council put the Customs $U$ nion between Turkey and the $\mathrm{EU}$ into effect, and there have been questions concerning its scope and functioning since then. With the increasing liberalization of trade at global scale, the EU has concluded trade agreements with third countries and blocs, which in turn jeopardize Turkey's rights and privileges gained by the Customs U nion. In this respect, this paper analyzes the current problems of the Customs Union with reference to the primary documents of EU-Turkey relations and offers recommendations. The first part presents some details of the Ankara Agreement, which constitutes the basis for EU-Turkey relations. The following part analyzes challenges derived from the structure of the association relations. Turkey's absence within the consulting and decision-making processes and gaps in the dispute resolution mechanisms are the two main challenges that complicate EU-Turkey relations. This paper argues that free trade agreements with third countries, the question of visa for Turkish nationals, and transport quota implemented to Turkish vehicles

\section{作}

* Assist. Prof., Marmara University, EU Institute, Department of EU Politics and International Relations, e-mail: egoral @ marmara.edu.tr.

** Prof. Dr., M armara University, EU Institute, Department of EU Economics, e-mail: mdartan@ marmara.edu.tr.

${ }^{* * *}$ Prof. Dr. Walter Hallstein, the First President of the Commission of the European Economic Community. From his speech on the occasion of the signature of the A ssociation A greement between European Economic Community and Turkey, A nkara, 12 September 1963. 
constitute the main obstacles against the proper functioning of the Customs Union. Therefore, the inclusion of Turkey to the decisions related to the customs union is necessary for a viable solution. Furthermore, this study stresses the importance of abolition of the visa regime for business purposes. Last but not least, this paper assesses that transportation quotas are in strict contradiction with the idea of a common market. In short, all these issues should be covered by a revision agreement since EU-Turkey relations has a sociological perspective as well as its economic and political aspects.

Keywords: Customs Union, Accession Negotiations, Visa Problem for Turkish Citizens, Transportation Quotas, EU Trade Agreements with Third Countries

\section{A B-TÜRKIYY İLIŞKILLERİ BAĞLAMINDA GÜMRÜK BİRLİĞİ: GÜNCEL TARTIŞMALAR ÜZERİNE BİR DEĞERLENDİRME}

\section{$\ddot{O} z$}

1/95 Sayılı Ortaklık Konseyi Kararı ile başlayan Türkiye ile Avrupa Birliği (AB) arasındaki Gümrük Birliği geçen süre içinde farklı sorunlarla gündeme gelmiştir. Dünyada ticaretinde artan liberalizasyonun etkisiyle AB farkl ülkeler ve ülke gruplarlya yeni ticaret anlaşmalar yapmış ve Türkiye'nin Gümrük Birliği ile elde ettiği kazanımları sorgulanmaya başlanmıştır. Bu çerçevede bu çalışma Türkiye'nin AB ile ilişkisinin temel metinlerini dikkate alarak bugün yaşanan sorunların analizini yapmakta, ve ilişkilerin düzeltilmesi yolunda çözüm önerileri sunmaktadır. Çalışmanın ilk bölümünde Türkiye - AB ilişkilerinin temelini teşkil eden Ankara Anlaşması'nın oluşumu incelenmektedir. Ardından, müzakerelere sürecinde ilişkilerin temel bazı özelliklerinden kaynaklanan zorluklar ele alınmıştır. Bunların başında danışma ve karar mekanizmalarında Türkiye'nin yer almaması ve ihtilafların çözümündeki yetki sorunu gelmektedir. Bu çerçevede Gümrük Birliği ile ilgili; üçüncü ülkelerle yapılan serbest ticaret anlaşmaları, Türk vatandaşlarının vize sorunu ve taşımacıllk kotalarl ile oluşan ticaret engelleri en önemli sorunlu alanlar olarak ortaya çıkmaktadır. Bu çalışma Gümrük Birliği ile ilgili sorunların ortadan kalkması için -her ne kadar Türkiye AB üyesi olmasa dakarar mekanizmalarında Türkiye lehine iyileştirmeye gidilmesinin gerekliliğini ortaya koymaktadır. Ayrıca, ticari amaçla uygulanan vizenin de Gümrük Birliği'nin önündeki engellerden biri olduğu, bu sebeple yapılacak bir güncellemede bu konunun çözülmesinin gerekliliğine vurgu yapılmaktadır. 
Ortak pazar ideali ile çelişen taşımacılık engellerinin de gerçekleştirilecek bir revizyonda ele alınmasının kaçınılmaz olduğu teyit edilmektedir. Çalışma son olarak Türkiye-AB ilişkilerinin ekonomik ve siyasi boyutunun yanı sıra sosyolojik bir yönünün olduğunu hatırlatmakta ve ucu açık bir müzakelerin Türkiye'de AB'ye olan güveni olumsuz etkilediğini iddia etmektedir.

Anahtar Kelimeler: Gümrük Birliği, Müzakere Süreci, Vize Sorunu, Taşıma Kotaları, AB'nin Üçüncü Ülkelerle Yaptı̆̆ Ticaret Anlaşmaları

\section{Introduction}

The relationship between Turkey and the European U nion (EU) has its roots in economic cooperation, which was designed by the Association A greement signed in 1963. The primary target of that agreement was to set up a customs union between Turkey and the then European Economic Community (EEC), which expects to reach an integrated market among its member states. The accession process of Turkey to the EU has currently exceeded half a century and throughout the process many other European countries manage to join the EU before Turkey. Being aware of the fact that the EU is the most advanced regional integration process, Turkey sticks to the path to the EU yet gets stuck in a series of accession criteria.

At the 1999 Helsinki European Council on 12/13 December 1999, the leaders of the EU recognized Turkey as a candidate country. However, the opening of accession negotiations was conditional on the fulfillment of the Copenhagen political criteria. The European Commission confirmed in its "Progress Report for Turkey 2004" that the political criteria were adequately fulfilled by Turkey. Thereupon the European Council decided at its meeting on 16/17 December 2004 on the opening of accession negotiations with Turkey. Based on that Council decision, the accession negotiations started on 30 ctober 2005 and the process is currently continuing.

This study aims to evaluate the impact of the Customs Union on Turkey's accession to the EU with its political, economic and legal consequences. In this way, this study may be evaluated as a contribution to current debates on the revision of the Customs Union, therefore it begins with a synopsis of EUTurkey relations, which will help to understand the current structure of Turkey's accession to the EU. The following part examines the details of the Customs Union and its defected structure after the current developments in EU's foreign trade relations. Finally, this paper argues that a revision of the 
Customs U nion between Turkey and the EU is necessary. W ithout taking firm steps in the current structure of the Customs Union, it is not possible to improve EU-T urkey relations.

\section{A B rief O verview of EU-Turkey Relations}

Since the early 1800s Turkey has been directed towards the developing Western countries and engaged in a series of Westernization efforts. In July 1959, the final step of this orientation was Turkey's application to the newly born EEC. Similar to their simultaneous membership to the Council of Europe in 1949 and NATO in 1952, Turkey and Greece acted together for the membership of Western European economic integration process as a part of their foreign policies. In other words, Turkey and Greece were eager to be aligned with the Western camp in a bi-polar world order. Therefore, it is not only the economic concerns of the post-World War II period but also the political motivation of these two neighbors that started the decision to get in a process of association partnership with the EEC.

The association partnership agreements with these two Southeast European countries were signed in 1961 and in 1963 with Greece and Turkey, respectively. The association agreement with Greece is known as the $A$ thens A greement and with Turkey is known as Ankara A greement ${ }^{1}$ or A ssociation A greement, or with its original title: 'The A greement establishing an A ssociation between the European Economic Community and Turkey'. The A nkara A greement aimed at a process of economic cooperation that would pave the way to the EEC membership. According to Article 237 of the Treaty of Rome, to be a European state was a prerequisite for membership. The Ankara A greement, in that sense, is a document demonstrating EEC's confirmation of Turkey's character as a European state (Göral, Özdemir, Y urtkoru, \& Dartan, 2014: 130).

The First Commission President W alter Hallstein stressed the importance of the A nkara A greement:

We are today witnessing an event of great political significance. Turkey is a part of Europe. That is really the ultimate meaning of what we are doing today. It confirms in comparably topical form a truth which is more than the summary expression of a geographical concept or of a historical fact that holds good for several centuries... And one day the

\section{minn}

${ }^{1}$ In this paper, the terms 'A nkara A greement' and 'A ssociation A greement' are used interchangably in order to define The Agreement establishing an A ssociation between the European Economic Community and Turkey(1963). 
final step is to be taken: Turkey is to be a full member of the Community. ${ }^{2}$ (Hallstein, 1963: 1-3)

Walter Hallstein's speech at the signing ceremony of the Association A greement between Turkey and the EEC was historically important since the then Commission President overtly confirmed Turkey as a part of Europe (Karluk, 1997: 7). As Hallstein observed the delegations share common prospects for the future of relations:

The mutual understanding shown by both delegations - the Turkish of the ideals and principles of the Treaty of Rome, and ours of the conditions obtaining in Turkey- shows that our association has foundations which justify the brightest hopes because they rest on a Community spirit: on an attitude of openness and solidarity (Hallstein, 1963: 2).

Turkey's leadership of the 1960s was also committed to the process as the then Turkish Prime M inister Inönü defined the Common M arket as 'the most courageous event in history'. Ismet Inönü further stressed that Turkey and Europe was permanently tied with the A nkara A greement (Ortak Pazara Girdik, 1963). It is possible to argue that the political atmosphere of the Cold W ar was one of the main reasons for Turkey and Europe to cooperate within the EEC structure as well as NATO and Council of Europe.

This argument may also be sufficiently supported when the responses of domestic actors in Turkey to the Ankara A greement are examined. Except for some marginal political groups, the association agreement had a positive welcome in Turkey. Concerns were restricted mostly to economic interests:

Those who opposed the relationship between Turkey and the Community took the view that, with an underdeveloped economy, Turkey would not fare well through entering the Common Market. This is because the countries that possessed better means of production than Turkey would use Turkey as a market and Turkish producers would be unable to compete. (Göral et al., p.131)

However, the unilateral concessions made by the EEC in order to help Turkey improve its economic conditions during the transition period proved the opposite. During this period, the EU lifted quotas and tariffs on industrial products originating from Turkey while Turkey abolished quotas and tariffs for the same group of goods in a schedule of 22 years.

\section{octom}

${ }^{2}$ On the occasion of the signature of the Association Agreement between European Economic Community and Turkey, A nkara, 12 September 1963. 
The Association Agreement defined the framework of the relationship between Turkey and the EEC. Article 28 of the agreement clearly stated that Turkey's final step would be membership of the Community when Turkey is fully capable to implement the acquis communautaire. Put it differently, as stated in the Ankara Agreement, "as soon as the operation of this Agreement has advanced far enough to justify envisaging full acceptance by Turkey of the obligations arising out of the Treaty establishing the Community, the Contracting Parties shall examine the possibility of the accession of Turkey to the Community." (Ankara Agreement, 1963).

\section{The stages of association agreement}

A three-period plan was scheduled for Turkey's way to membership by the Association Agreement in 1963 (Figure 1). The Preparatory Stage, the Transition Stage, and the Final Stage of the agreement had different yet complementary aims, which would help Turkey to become a member of the Community. An in-depth analysis of each stage is necessary to comprehend the current state of relations.

Figure 1: Stages of Turkey - EEC Partnership Agreement
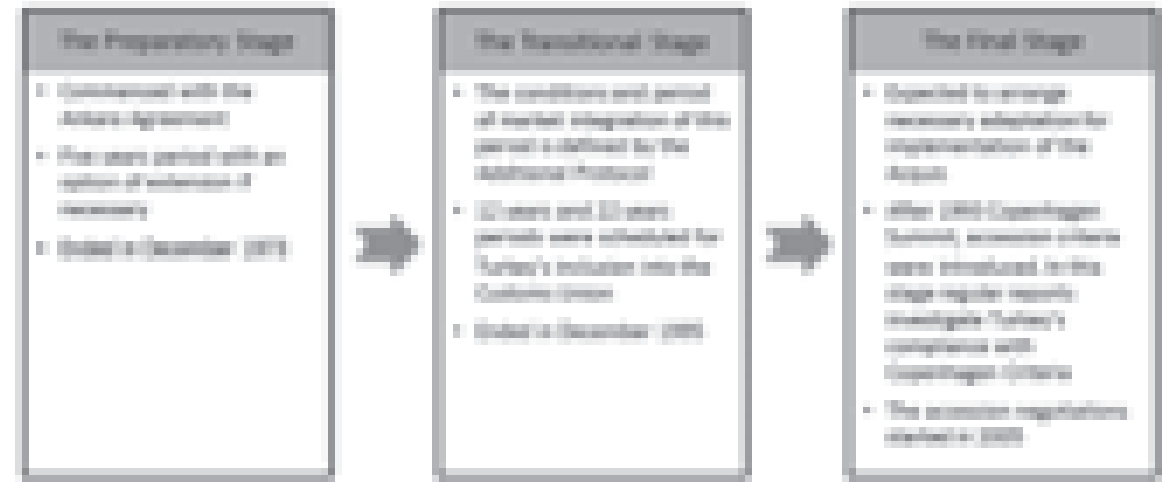

\section{The Preparatory Stage}

In the early 1960s Turkey and the EEC members had very different economic structures. Turkey's economy was based mostly on agricultural products while the EEC members were powerful economies in terms of industrial development. Therefore, being a member of the common market in the 1960s could have catastrophic economic consequences on Turkey's economy. 
From this point of view, the A ssociation A greement envisaged a preparatory stage of at least five years for Turkey, which could be prolonged for an additional five years. During this period, the EEC accepted a discounted tariff on four of Turkey's traditional products, which are hazelnut, raisin, dried fig and tobacco. Furthermore, EEC was ready to provide a loan of 175 million ECU in this period. On the other hand, Turkey's liability for this period is to strengthen its economy in order to be able to compete with other European economies.

In contrast with the purpose of this period, there were no significant developments in Turkey's economy. It is also worth mentioning that the EEC was politically stagnant during the second half of the 1960s. N either Turkey nor the EEC put sufficient effort into attaining the targets of this period. Finally, the end of this period was delayed until the implementation of the Additional Protocol in J anuary 1973.

\section{The Transitional Stage}

Considering the delay in the initial stage, the Turkish delegation and officials of the European Communities ${ }^{3}(E C)$ started to negotiate the situation by the end of 1968. On 23 November 1970, an A dditional Protocol was signed between Turkey and the $\mathrm{EC}$ as a part of the A ssociation A greement. According to the Additional Protocol, a new path for achieving the Customs Union was designed with a step-by-step process. The process required responsibilities both for Turkey and the EC. In more concrete terms, a period of 12 years was determined for the free movement of goods, with the exception of freedom in certain sensitive goods for a period of 22 years. A $n$ interim protocol was signed for the necessary arrangements between the signing of the Additional Protocol and its implementation.

According to Article 9 of the Additional Protocol, the EC members unilaterally abolished customs duties and other charges with equivalent effects as well as quota restrictions for Turkey's products. On the other hand, Turkey's responsibility for removing all the barriers against free trade was settled in a period of 22 years depending on the product type. In other words, the final stage was expected to begin with the introduction of the Customs U nion as of 1 J anuary 1996.

\section{(19)}

${ }^{3}$ A fter the Merger Treaty (1967) the EEC, Euratom and European Coal and Steel Community were merged under a unique institutional structure known as 'the European Communities'. 
The hazy atmosphere of European integration during the 1970s had also negatively affected EU-Turkey relations. During the stagnation of the world economy as a result of the oil crisis, Turkey was a long way off achieving the objectives defined by the A dditional Protocol. In 1980 Turkey had experienced a coup d'etat which strained relations between Turkey and the European Communities. A fter Turkey's conversion to democratic governance by the 1983 elections, a new government was eager to recommence relations with the EC.

Consequently, Prime M inister Turgut Özal's government applied for full membership on A pril 1987. Turkey's application was contrary to the schedule determined by the Additional protocol, yet clearly based on A rticle 237 of the Treaty of R ome (Özen, 2002: 120-121). It is obvious that the Özal Government was influenced by the international political developments of that period. In other words, the accession of Greece in 1981 followed by the Iberian countries in 1986 encouraged Turkey about the willingness of EC in favor of a further enlargement. M oreover, the difficulties within the Soviet Bloc also gave Turkey the impression that Eastern European countries would edge ahead in EC membership (Göral et al., 134). Deepening efforts of EC after the Single European A ct may also be another factor that influences Turkey for an early application. The deepening would result in additional requirements for Turkey.

The Commission of the $\mathrm{EC}$ responded Turkey's application almost after two years of evaluation period. Although confirming Turkey's eligibility for EC membership, the Commission recommended to resume existing association process at a deeper level. In line with the Commission's recommendation, the Council asked the Commission to prepare a detailed proposal for strengthening the relations with Turkey. Six months later the Commission responded with the $M$ atutes Package which proposes (1) fulfillment of the Customs Union, (2) active financial cooperation, (3) political dialogue, and (4) economic cooperation. A fter this futile attempt of Turkey, the international politics had changed significantly and the EC adopted itself to the changing conditions with a new enlargement and deepening agenda.

\section{The Final Stage}

By the end of 1995 the European U nion had a new outlook with 15 member states including Sweden, Finland and A ustria. M oreover, the M aastricht Treaty paved way to a pillar structure in which member states were expected to increase their cooperation in the areas of foreign and security policy as well as justice and home affairs. In other words, Turkey's path to EU became more complicated after the widening and deepening of the 1990s. The final stage of 
association agreement was started in a period when the EU was adopting itself to the new world order. With the Decision No 1/95 of $6 \mathrm{M}$ arch 1995 the Customs Union between Turkey and the EU members was established as defined in the A ssociation A greement and the A dditional Protocol.

Between October 2001 and A ugust 2002, Turkey achieved a series of reforms packages defined in its $\mathrm{N}$ ational Programme. The first JDP Government also carried on with the ongoing EU process and at the Copenhagen European Council, the EU leaders decided that negotiations with Turkey should commence by the end of 2004. A s a result, the negotiations with Turkey started on 3 October 2005. The Union defined the accession negotiations as an open process. Some decisions of the December 2004 European Council summit have special importance for Turkey. Negotiation framework envisaged for Turkey differs from previous enlargement experiences and entails a 'special treatment'. As the EU decisions on Turkey clearly puts forward:

[... L Long transitional periods, derogations, specific arrangements or permanent safeguard clauses, i.e. which are permanently available as a basic for safeguard measures, may be considered. The Commission will include these, as appropriate, in its proposals for each framework, for areas such as freedom of movement of persons, structural policies or agriculture. Furthermore, the decision-making process regarding the eventual establishment of freedom of movement of persons should allow for a maximum role of individual Member States. Transitional arrangements or safeguards should be reviewed regarding their impact on competition or the functioning of the internal market. [... ] (European Council, 2004: 7)

As shown in the Table 1, Negotiations with Turkey is conducted under 35 main chapters.

Table 1: Negotiation Chapters of the A cquis

1. Free M ovement of Goods

2. Free M ovement of $W$ orkers

3. Right of Establishment and Freedom to Provide Services

4. Free M ovement of Capital

5. Public Procurement

6. Company Law

7. Intellectual Property Law

8. Competition Policy
18. Statistics

19. Social Policy and Employment

20. Enterprise and Industrial Policy

21. Trans-European N etworks

22. Regional Policy and Coordination of Structural Instruments

23. Judiciary and Fundamental Rights

24. Justice, Freedom and Security

25. Science and Research

26. Education and Culture 
9. Financial Services

10. Information Society and M edia

11. A griculture and Rural Development

12. Food Safety, V eterinary and

Phytosanitary Policy

13. Fisheries

14. Transport Policy

15. Energy

16. Taxation

17. Economic and M onetary Policy
27. Environment

28. Consumer and $\mathrm{H}$ ealth Protection

29. Customs Union

30. External Relations

31. Foreign, Security and Defense Policy

32. Financial Control

33. Financial and Budgetary Provisions

34. Institutions

35. Other Issues

Since 2005, only 16 of the 35 chapters have been opened as of J une 2016, and only one of them (Chapter 25) was provisionally closed. Currently, 8 chapters are suspended by the EU and 2 chapters are blocked by France (Chapter 11 is blocked both by France and the EU Council). South Cyprus ${ }^{4}$ blocked another 6 chapters. There are still 3 chapters ready to open negotiations, which are Chapters 5, 8 and 19. Chapter 35 will cover other issues and will be opened after all of the chapters are closed.

\section{T able 2. C hapters 0 pened}

\begin{tabular}{|c|c|}
\hline Chapter 4 & F ree M ovement of Capital \\
\hline Chapter 6 & Company Law \\
\hline Chapter 7 & Intellectual Property Law \\
\hline Chapter 10 & Information Society and M edia \\
\hline Chapter 12 & Food Safety, V eterinary and Phytosanitary Policy \\
\hline Chapter 16 & Taxation \\
\hline Chapter 17 & E conomic and M onetary Policy \\
\hline Chapter 18 & Statistics \\
\hline Chapter 20 & E nterprise and Industrial Policy \\
\hline Chapter 21 & Trans-European N etworks \\
\hline Chapter 22 & Regional Policy and Coordination of Structural Instruments \\
\hline Chapter 25 & Science and Research \\
\hline Chapter 27 & Environment \\
\hline Chapter 28 & Consumer and $\mathrm{H}$ ealth Protection \\
\hline Chapter 32 & Financial Control \\
\hline Chapter 33 & Financial and Budgetary Provisions \\
\hline
\end{tabular}

(1)

${ }^{4}$ Republic of Cyprus. Turkey does not recognize Greek Cypriots as the Republic of Cyprus. 
Table 3. C hapters B locked for Negotiations

\begin{tabular}{|c|c|c|c|c|c|}
\hline \multicolumn{2}{|r|}{ EU C ouncil } & \multicolumn{2}{|r|}{ France } & \multicolumn{2}{|r|}{ Cyprus } \\
\hline Ch.1 & $\begin{array}{l}\text { Free M ovement of } \\
\text { Goods }\end{array}$ & Ch.11 & $\begin{array}{l}\text { A griculture and } \\
\text { Rural Development* }\end{array}$ & Ch. 2 & $\begin{array}{l}\text { Free M ovement of } \\
\text { W orkers }\end{array}$ \\
\hline Ch.3 & $\begin{array}{l}\text { Rights of } \\
\text { Establishment and }\end{array}$ & Ch. 17 & $\begin{array}{l}\text { E conomic and } \\
\text { M onetary Policy** }\end{array}$ & Ch. 15 & Energy \\
\hline & $\begin{array}{l}\text { Freedom to Provide } \\
\text { Services }\end{array}$ & Ch. 22 & $\begin{array}{l}\text { Regional Policy and } \\
\text { Coordination of }\end{array}$ & & $\begin{array}{l}\text { Fundamental } \\
\text { Riahts }\end{array}$ \\
\hline Ch.9 & Financial Services & & Structural & Ch.24 & J ustice, Freedom \\
\hline Ch.11 & A griculture and & & Instruments** & & and Security \\
\hline & $\begin{array}{l}\text { Rural } \\
\text { Development* }\end{array}$ & Ch. 33 & $\begin{array}{l}\text { Financial and } \\
\text { Budgetary }\end{array}$ & Ch. 26 & $\begin{array}{l}\text { Education and } \\
\text { Culture }\end{array}$ \\
\hline Ch.13 & Fisheries & & Provisions** & Ch. 31 & Foreign, Security \\
\hline Ch.14 & Transport Policy & Ch.34 & Institutions & & and Defense \\
\hline Ch. 29 & Customs Union & & & & Policy \\
\hline Ch. 30 & External Relations & & & & \\
\hline
\end{tabular}

* This chapter has been blocked both by the EU and France.

** France later abolished its veto on these chapters and these chapters are opened for negotiations.

\section{The C ustoms Union between T urkey and the E uropean Union}

The Customs Union has since its launch recorded a major improvement trend, but is facing certain problems, which requires a fundamental reform of the Customs Union. The problem areas that necessitate urgent change in the Customs U nion between the Turkey and EU can be listed as follows:

- lack of decision-making capacity of Turkey about the issues related to the Customs U nion;

- visa requirement for Turkish businessmen;

- free trade agreements that the EU negotiates with third countries without a simultaneous involvement of Turkey;

- and limitations over Turkey's quote for freight transport within the EU territories.

It is necessary to evaluate the troubled aspects of the Customs Union in order to understand the current deadlock in EU-Turkey relations. Therefore, this part evaluates the problematic issues, which contradict with the spirit of the Customs U nion between Turkey and the EU. 
Background of EU - Turkey Customs U nion Relationship

When the Customs Union, which was envisaged as the final phase of Turkey's association process prior to full membership, entered into force on 1 J anuary 1996, both Turkey and the EU were hopeful about the consequences of abolishing existing impediments against free trade. First, the Customs Union considerably increased competitiveness in Turkey's manufacturing sectors. When Turkey's products began to meet various EU standards, the demand for Turkish exports in the European market rose significantly. The bilateral trade of US\$ 28 billion in 1995 has increased to approximately US\$ 158 billion in 2014, making Turkey the sixth-largest trading partner, while the EU has become Turkey's primary trade partner (World Bank, 2014: 3). In addition, Foreign Direct Investment (FDI) in Turkey was also another indication of the positive trend in foreign trade between the EU and Turkey. FDI inflows to Turkey peaked in 2007 at US\$ 19.1 billion and increased in M ay 2013 to a total of US\$ 75.5 billion, of which $75 \%$ (US\$ 56.6 ) billion came from European countries. (W orld B ank, 2014: 5-6)

In point of fact, the EU expected to expand the internal market through the inclusion of Turkey in the Customs U nion. On the other hand, Turkey, in return for entry into the tough competition with European manufacturers, preferred to discipline its production capabilities as well as the business environment so that Turkey could compete on an international level with the financial assistance of the EU. A ccording to the Ankara A greement and the A dditional Protocol, the free circulation of goods was the first among the "four freedoms" which was necessary for Turkey's integration into the Europe. In more concrete terms, it was still necessary to provide the free movement of persons, capital and services in order to start negotiations with Turkey.

It should be noted that Turkey has not received adequate support from the EU with regard to problems of competitiveness and adjustment costs resulting from the opening up of its market, while undertaking all obligations arising from the Customs Union (Kabaalioğlu, 2012, p.16).

Therefore, the Customs U nion between Turkey and the EU is not the final aim and the relations were expected to go beyond a customs union in the strict sense, which was considered in the A nkara A greement as the final stage before full membership as described in the preamble of the Decision No 1/95 of the EU-Turkey A ssociation Council of 22 December 1995 on Implementing the final phase of the Customs U nion, 96/142/EC (1996): 
Considering that the objectives set out by the A nkara A greement, and in particular by its Article 28, which established the A ssociation between Turkey and the Community maintain their significance at this time of great political and economic transformation on the European scene; [... ]

Considering that the A ssociation relations as provided for in Article 5 of the Ankara A greement are entering into their final phase based on the Customs Union, which will complete the transitional phase through the fulfillment by the two parties of their reciprocal obligations and which leads to the elaboration of the modalities for the effective functioning of the Customs Union within the framework of the A nkara Agreement and Additional Protocol;

Considering that the Customs U nion represents an important qualitative step, in political and economic terms, within the Association relations between the Parties.

A rticle 28 of the A nkara Agreement provides for the full membership of Turkey following the implementation of the Customs Union between the parties (A nkara A greement, A rticle 28):

As soon as the operation of this A greement has advanced far enough to justify envisaging full acceptance by Turkey of the obligations arising out of the Treaty establishing the Community, the Contracting Parties shall examine the possibility of the accession of Turkey to the Community.

\section{Consulting and Decision-M aking P rocess}

A fter the Customs Union with the EU, Turkey has applied some common principles of the EU Member States. This poses on Turkey a risk of being bound by all the obligations of the member states even against third countries albeit not being present in the decision making process. Currently, Turkey is one of few countries that have a Customs Union with the EU without being a member state. The other states that have also a Customs U nion without being a member states are San Marino and Andorra. These are miniscule states that cannot be compared to Turkey.

This means that Turkey would assume -as the only one non-member country that has a customs union with the EU-all kinds of obligations of the Union without participating in the decision-making processes of the Union. ${ }^{5}$

\section{1}

${ }^{5}$ For more detailed evaluation of responsibilities posed on Turkey after the Customs U nion, see D artan (2002: 284). 
Kabaalioğlu (2012) contends that the Decision No 1/95 of the EU-Turkey A ssociation Council contains 7 detailed articles on 'consultation and decisionmaking processes' (Article 54-60) regarding 'areas of direct relevance to the operation of the Customs U nion'. These areas

[... ] shall be commercial policy and agreements with third countries comprising a commercial dimension for industrial products, legislation on the abolition of technical barriers to trade in industrial products, competition and industrial and intellectual property law and customs legislation (A rticle 54/2).

When new legislation is drawn up by the European Commission in an area of direct relevance to the functioning of the Customs U nion, the Commission shall consult Turkey informally and submits copies of the proposal to Turkey (A rticles 55/1 and 55/2). Furthermore, another consultation mechanism is defined by the Article 55. The Parties may consult, on request of either party, by the Customs U nion J oint Committee on the Customs Union during the phase prior to the EU Council decision (A rticle 55/3). These parties are also required, during the information and consultation phase in good faith to cooperate with each other "with a view to facilitating, at the end of the process, the decision most appropriate for the proper functioning of the Customs Union" (A rticle 55/4).

However, this advice mechanism is far from protecting the interests of Turkey in the negotiations on free trade agreements between the EU and third countries, which constitute an important aspect in the formation of the EU's common commercial policy. In the event that this consultation process does not function quickly and efficiently enough, as in A rticle 58/2 of the Decision No $1 / 95$ was set out that under certain conditions, the parties have the right to take immediate protective measures. A ccordingly:

If discrepancies between Community and Turkish legislation or differences in their implementation in an area of direct relevance to the functioning of the Customs Union, cause of threaten to cause impairment of the free movement of goods or deflections of trade and the affected Party considers that immediate action is required, it may itself take the necessary protection measures and notify the Customs Union Joint Committee thereof; the latter may decide whether to amend or abolish these measures. Priority should be given to measures which least disturb the functioning of the Customs Union. (A rticle 58/2) 


\section{Dispute Resolution}

The EU Courts (the Court of First Instance and the European Court of Justice) settle any disputes between the EU and the Member States. In the association relations between Turkey and the EU, there are no provisions that transfer such an authority directly to the courts of the EU.

If a dispute arises concerning the interpretation or application of the A ssociation A greement between Turkey and the EU, the parties (Turkey, the Community and the Member States) can resort to the Association Council (A rticle 25 of the Association A greement). Legal persons have no right to conduct the Association Council. The Association Council settles disputed issues with a decision and its decision is binding on all parties. Since the decisions in the Association Council are taken by unanimity, the Association Council cannot be able to settle a dispute. In that case, it may decide to refer the dispute to the European Court of Justice (ECJ), or other existing court or tribunal (Article 25/2). However, this transfer also requires a unanimous decision of the parties concerned.

Therefore, the dispute will remain unsettled when one of the parties (T urkey or the Community) refuses to take the case to the European Courts or another court or tribunal. This demonstrates a clear institutional weakness for the association relationship, particularly about the Customs U nion. In the Decision No 1/95 of the Association Council an arbitration process to resolve disputes was provided (A rticle 61 and 62). This process, however, has not yet found application.

\section{The Areas of Problem with the C ustoms Union}

Although the Customs Union constitutes the framework of currently relationship between Turkey and the EU various problems emerged in time that needs to be revised. In this section some of the main issues ${ }^{6}$ will be discussed which have been encountered in the association relations between Turkey and the EU, particularly with regard to the Customs U nion.

\section{F ree Trade Agreements with Third Countries}

One of the main problems encountered in the context of the Customs U nion between Turkey and the EU is the free trade agreements with third countries. Because Turkey is not a member state of the EU Turkish officials cannot 
participate in the negotiations of free trade agreements that have been concluded by the European U nion with third countries. As a result, Turkey's concerns and expectations cannot be presented during the negotiation process despite the fact that a new free trade agreement (FTA) has an impact on Turkey's economy. The negative impact of Turkey's absence in trade negotiations become obvious when the importance of Turkey as a trading partner of the EU and the size of its economy as the $16^{\text {th }}$ largest economy in the world are considered. Furthermore, it cannot be overlooked the fact that if the EU is negotiating a free trade agreement, this agreement covers not only 28 M ember States but also Turkey, which is part of the 'customs area'.

In the process of concluding a FTA with a third country, the EU prefers to make an impact assessment and to define a common position by considering sensitive sectors for the EU. After this process, the U nion asks Turkey to conclude a similar FTA with the third country involved (the so-called "Turkey clause" in agreement). The problems here are, firstly, such clauses are not legally binding for a third country, and secondly, the negotiations with Turkey should not necessarily begin until the FTA with the EU enters into force. These problems may cause severe economic consequences for Turkey because a third country al ready receives the trade benefits and access to the Turkish market as a result of the existing Customs Union between Turkey and the EU when that country signs a free trade agreement with the EU. However, third parties generally have no further interest in the signing of an additional free trade agreement with Turkey, which would provide similar benefits to Turkey. In the W orld B ank report (2014), this point is evaluated:

However Turkish firms have not received automatic reciprocal access to some of those markets with which the EU has negotiated FTAs, leaving them at a competitive disadvantage to EU exporters, weakening Turkey's trade negotiating position with these countries and causing trade deflection that risks the imposition of origin controls that could undermine the benefits of the $\mathrm{CU}$. Where the EU has provided leverage to Turkey in concluding FTA s with third countries that might not have otherwise happened in the absence of the $\mathrm{CU}$, this has brought important benefits. However, in those cases where the EU has concluded an FTA with a third country but Turkey has not, exporters have an incentive to transship goods via the EU resulting in trade deflection. (p. 25)

The negative impact of the EU 's free trade agreement with third countries on the Turkish economy could be disregarded if the third countries concerned have not an intensive economic activity or they are not competitors of Turkey in terms of product variety and quality. However, negotiations conducted with 
some of the third countries like India and China or a block of countries like A SEAN ${ }^{7}$ and Mercosur $^{8}$ cause serious difficulties for Turkey (Akses, 2010; Taşdemir, 2008). ${ }^{9}$

One of the most feasible solutions to alleviate the concerns raised by this problem would be to promote separate negotiations on the free trade agreement between Turkey and the third countries with which the EU signs trade agreements. However, this should take place in parallel with the EU (here the consultation process of Decision No 1/95 can be resorted) to conclude such agreements and to enter into force simultaneously. A nother option for a probable solution might be a requirement of a specific time frame for starting negotiations with Turkey 'no later than' a few months after the FTA enters into force.

The increasing economic size of the third parties that the EU has negotiated with recently has made Turkey more anxious about this problem. In other words, the ongoing negotiations between the US and the EU over the Transatlantic T rade and Investment Partnership (TTIP) makes the problem even more topical than ever for Turkey. ${ }^{10}$ According to Kirişci and Ekim (2015)

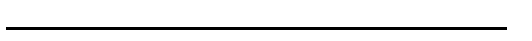

${ }^{7}$ A SEA N is the A ssociation of South East A sian Nations among the countries including B runei, Cambodia, Indenosia, Laos, Malysia, M yanmar, the Philipinnes, Singapore, Thailand, and V ietnam.

${ }^{8}$ Mercosur is the Southern Common Market among some of the Latin American countries including A rgentina, B olivia, B razil, Paraguay, U ruguay and $V$ enezuela.

9 "Currently, the EU has FTAs with 48 countries while Turkey has concluded FTAs with just 19, two of which the EU does not have FTAs with (Syria and Georgia). Turkey has 17 FTAs in force, namely with EFTA, M acedonia, B osnia-Herzegovina, Albania, Israel, Palestine, Morocco, Tunisia, Egypt, Syria (suspended), Georgia, Serbia, M ontenegro, Chile, Jordan, South K orea and M auritius. A greements with Lebanon and Kosovo will be in effect after the completion of internal ratification procedures. Meanwhile, there are 14 countries/country blocs that Turkey has started FTA negotiations; namely Peru, Ukraine, Colombia, Ecuador, M alaysia, M oldova, Dem. Rep of Congo, Ghana, Cameroon, Seychelles, Gulf Cooperation Council, Libya, M ercosur and Faroe Islands. M oreover, Turkey has launched initiatives to start negotiations with 12 countries/country blocs, which are the USA, Canada, Japan, Thailand, India, Indonesia, Vietnam, Central American Countries, other ACP Countries, Algeria, M exico and South A frica" (World Bank, 2014: 25).

${ }^{10}$ TTIP is a proposed free trade agreement between the EU and the US, with the aim of promoting multilateral economic growth. The exact terms and conditions of TTIP are negotiated since July 2013. The aim of TTIP is, according to the negotiators, the reduction of tariff and non-tariff barriers. This reduction is to promote economic growth and to reduce costs for exporting companies in the EU and the US. Due to the large economic importance of the EU and the US ( $50 \%$ of global gross domestic product) 
Turkish academic, bureaucratic, and business circles have increasingly become aware of the fact that an economy based on foreign resources cannot be sustainable unless it takes part in emerging trading regimes. Y1lmaz (2015: 3) explains the possible impact of a US-EU trade agreement on third countries:

[... ] the resulting increase in the bilateral trade of the two countries will be at the expense of their respective trade with third countries. As the EU lifts the barriers to its imports from the US, A merican goods will start competing with goods from the EU's FTA partners, who previously enjoyed preferential treatment. The market share of the A merican goods will increase, while the respective market shares of the goods from the EU's preferential trade partners will decrease. Turkey could face a similar trade diversion effect in the case of the US market, but the size of this effect is likely to be much smaller compared to the one faced in the EU market [...] Turkey and the major developing and developed countries that are not part of the agreement will incur income losses.

As shown in Figure 2, the calculations made by Felbermayr and Larch (2013) depicts the welfare effect of a comprehensive free trade agreement between the EU and the US. Canada, A ustralia, M exico and J apan are the most notable trade partners, which will be negatively affected by an FTA. A ccording to that study, Turkey's loss will also be worth mentioning as it is approximately equal to 2.5 percent of the real income (around $\$ 20 \mathrm{bn}$ ).

Turkey's first priority to offset the negative economic consequences is deepening bilateral relations with the United States via a new FTA. However, the A merican Government has fully occupied its agenda with the negotiations for the TTIP and Trans-Pacific Partnership (Stevens, 2015). Therefore, the US may be reluctant to conduct a new agreement with Turkey. In light of this, what Turkey should search for is an alternative solution within the Customs Union in order to achieve its future economic objectives.

m m m m m m TTIP would potentially represent the largest free trade area. Trade between the EU and the US comprises about one-third of the global trade volume. In the year 2014, the EU exported goods worth $310.9 \mathrm{bn}$, services worth 193.6 bn euros to the US; exports from the US to the EU amounted to contrast in goods 206.5 bn in services 182.1 bn euros (EU Commission, 2015). 


\section{Figure 2: Welfare Effects of a Free Trade Agreement}

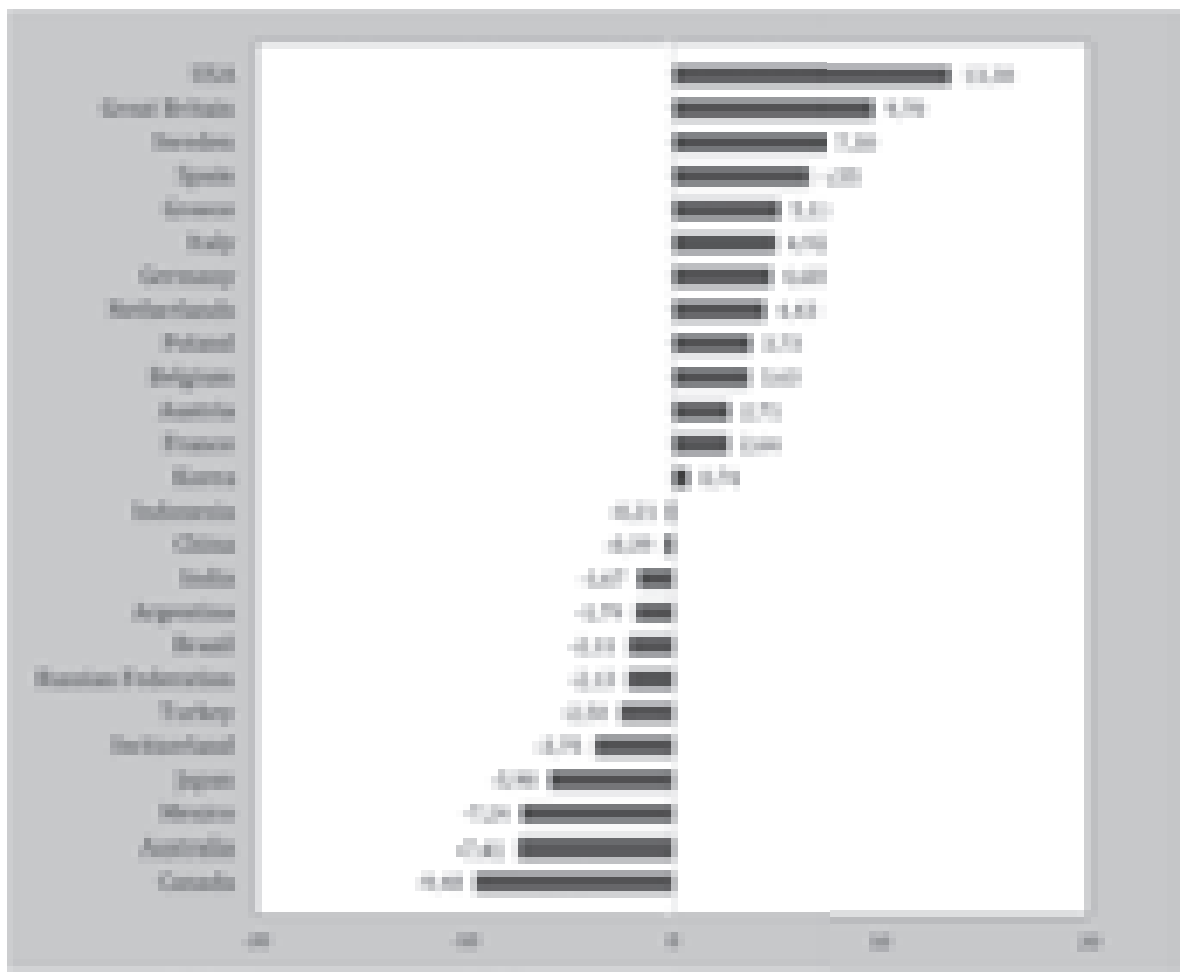

Source: Felbelmayr and Larch (2013)

Kirişci and Ekim (2015) contend that "upgrading the Customs Union will not only compensate for the disadvantages resulting from being left out of the TTIP, but also increase the prospects of a bilateral free trade agreement (FTA) with the United States." Similarly, Yilmaz (2015) argues that TTIP is an opportunity for the further integration of the Turkish economy with that of the EU. According to Yilmaz "as part of an effort to deepen the Customs Union, the EU should ask for Turkey to implement the incorporation within the Customs Union of the hitherto excluded services, agriculture, and public procurement, as well as stricter enforcement of the legislation on intellectual property rights" (Y1lmaz, 2015: 7). Nevertheless, these steps will force Turkish businesses to adapt to new rules and regulations while facing increased competition in the domestic market. 
The question of visa for Turkish nationals

The 'visa problem' that EU member states have required for Turkish nationals since the year 1980 has been another complicated issue that contradicts the primary principles of a customs union. The visa issue covers a wide range of perspectives including legal, social, diplomatic, bureaucratic, administrative and technical; and each of these aspects has diverse and complicated reflections. Studies presenting solutions covering all of these aspects, however, are insufficient.

The fact that a visa requirement for T urkish businessmen and self-employed persons, who want to build a business and to provide services is not only an unfair practice but also as a whole incompatible with the spirit of the Customs Union. The visa requirement is a clear impediment to Turkish nationals who travel for various business activities, i.e.: participating in exhibitions, appealing to tenders or investigating investment opportunities. The World Bank report confirms the situation with some statistical data:

While the visa regime applied by the EU towards Turkish professionals is the same as towards other visa countries (including those that have an FTA with the EU), visa processes are among the leading complaints by Turkish businessmen and professionals on the CU implementation process. The complaints include a range of issues including high fees, short duration and single entry visas, uncertainty in the review process and excessive paperwork. In 2010, 625,000 Turkish nationals applied for travel visas to visit EU member states. Visa fees paid by Turkish nationals for type $C$ visas (short-stay visas issued for one, two or several visits. Its period of validity varies and allows stays which do not exceed three months over a six-month period) were $€ 100$ million per year between 2009-11 (World B ank, 2014: 77-78).

From the legal perspective visa implementation on Turkish nationals by the EU countries since the 1980 s has been a topical subject due to current developments. According to Article 36 of the Additional Protocol, the free movement of workers between the Member States of the Community and Turkey is secured. Article 48, 49 and 50 of the Treaty Establishing the European Economic Community was expected to guide the free movement of the workforce between Turkey and the M ember States (Kabaalioğlu, 2012: 18). A lthough initially free movement of workers between Turkey and the M ember 
States was expected to be realized by 1986 , it is still not possible for Turkish nationals ${ }^{11}$ to visit any member state without a visa requirement.

In the last decade the ECJ has ruled cases in favor of Turkish nationals and this, in turn, has led to the confirmation of the rights of Turkey and Turkish nationals arising from the Association A greement. In February 2009, the ruling known as the Soysal Case was resulted in favor of the two Turkish nationals and it rallied the hope that the visa application will be lifted soon. The Soysal judgment based on article $41(1)$ of the Additional Protocol stated that Germany's visa application on Turkish nationals traveling to supply services is in contradiction with EU law.

A ccording to A rticle 41(1) of the Additional Protocol:

The Contracting Parties shall refrain from introducing between themselves any new restrictions on the freedom of establishment and the freedom to provide services.

The Demirel Judgment of the ECJ recognized the direct effect of certain international agreements. The Demirel Case is important since it reaffirms that "an agreement concluded by the Council under A rticles 228 and 238 of the Treaty is, as far as the Community is concerned, an act of one of the institutions of the Community within the meaning of Article 177 (1) (b), and, as from its entry into force, the provisions of such an agreement form an integral part of the Community legal system" (Case C-12/86). The Court further reiterates that A rticle 238 of the Rome Treaty brings the Community the responsibility to guarantee the commitments towards non-member countries in all fields covered by the Treaty.

As one of those agreements, the Additional Protocol brought in the 'standstill clause' (provided by the A rticle 41) which has direct effect in terms of community law. The Soysal Judgment, therefore, confirms that visa requirement for Turkish nationals is equal to a new restriction, which was not applied at the time of the A dditional Protocol entered into force. In other words, the ECJ has ruled that for those M ember States that had recognized the right of establishment and freedom to provide services for Turkish nationals before

\section{man}

${ }^{11}$ Special Passport holders have an exemption of the visa requirement for the Schengen A rea. All other Turkish nationals who has an ordinary passport have to get a visa before entering into Schengen $A$ rea. 
$1973,^{12}$ A rticle 41 (1) of the Additional Protocol lays down a total ban on the introduction of new measures and any kind of restrictions including the visa requirement.

As defined before, the legal status of the scope of Article 41 (1) of the A dditional Protocol has been set absolutely by the Soysal Judgment. In the period following the Court's decision, it was also important to ensure the implementation of these rights within the EU structure. Put differently, without fully applying the ECJ decision within the M ember States, the Soysal J udgment would not have any implication on Turkish nationals and Turkey. Indeed, the main problem about the visa issue arises at this point.

Initially, as the 'Guardian of the Treaties' it is the European Commission which should take the initiative to guarantee the application of ECJ judgments by the Member States. In practice, the Commission could list the member states, which can and cannot apply visa requirement for Turkish nationals according to the Soysal Judgment. However, the Commission failed to take progressive action after certain internal consultation within the EU structures. Indeed, the European Commission closely followed cases brought before the ECJ by Turkish nationals. In most of the cases the Commission supported Turkish nationals. The case against the Netherlands was about the high fees charged contrary to A rticle 9 of the Association A greement, Article 41 of the Additional Protocol and Article 10 and 13 of the Decision No. 1/80 of the A ssociation Council. ${ }^{13}$

In line with the guidelines developed as a part of the 'Practical Handbook for Border Guards' the Commission informs member states about the visa policy against Turkish nationals. The Schengen Handbook provided clarifications about the visa requirements for short term stays of Turkish nationals living in Turkey. The document reiterated the ECJ's decision:

Turkish nationals residing in Turkey and travelling to a M ember State in order to provide services there on behalf of an undertaking established in Turkey are not required to have a visa to enter the territory of that $M$ ember State, if the Member State in question did not require such a visa at the time of the entry into force, with regard to that M ember State, of the Additional Protocol of 23 November 1970 to the Agreement

\section{W}

${ }^{12}$ The date on which the Additional Protocol takes effect is 1 January 1973 for the founding Member States (Germany, France, Italy, the Netherlands, Belgium and Luxembourg) and it is the date of their accession for other $M$ ember States.

${ }^{13}$ The ECJ ruled that the N etherlands had violated these articles, see: Case C-92/07. 
establishing an Association between the EEC and Turkey of 12 September 1963 (European Commission, 2012)

Although that standstill clause freezes legislation at the date of the entry into force of the provision preventing parties from introducing any new restrictions on the freedom of establishment and the freedom to provide services, Groenendijk and Guild (2010) contend that from the date the Additional Protocol entered into force onwards, Member States have introduced new restrictions for Turkish nationals by applying visa requirements.

Interestingly, the situation has not changed after the Sosyal decision. Despite the decision of the ECJ, some countries (Belgium, France and the U nited $\mathrm{K}$ ingdom), which required no visas at the time of the entry into force of the Additional Protocol, have failed to remove the visa impediment while some member states such as Germany and Denmark have adopted the Soysal Decision in a restricted model, which is a misrepresents implementation. Thus, it can be argued that Soysal judgment has not yet been properly implemented by the M ember States.

In addition to the visa problem, language tests -sometimes combined with integration tests- are also used by some member states as a requirement for foreigners searching for residence permits. The Ayalti Case (Case C-513/12) and the Doğan Case (Case C-138/13) are important examples of the recent impediments against Turkish nationals. German Law gives the spouse of a foreigner who has a right of residence the right to join him or her if certain conditions are fulfilled. B eing able to express him or herself at least in a simple way in the German language is one of those requirements. When Doğan and A yalti took their cases as an impediment for family reunification against Germany, the Administrative Court of Berlin referred the question to the European Court of J ustice as to the compatibility of the language condition with the A ssociation A greement and the Additional Protocol.

The ECJ decided that the language requirement introduced in 2007 is not compatible with the standstill clause of the A ssociation A greement and "[... ] The requirement of a basic knowledge of the German language imposed by Germany as a condition for the issue of a visa for the purpose of reunification of spouses of Turkish nationals residing lawfully in its territory is contrary to EU law" (C ourt of J ustice of the European Union, 2014).

Filippin and Neuhwahl (2014: 124) contend that the judgment confirms a wide application of the standstill clause of the A ssociation A greement and the Additional Protocol, yet prudently reminds us that it is not a big step since it 
does not include a right of family reunion unless the conditions are tightened in an arbitrary or discriminatory way. In her salient study, 'No German, No Love', prior to the decision of the ECJ, Neuwahl's (2013) expectations about the Doğan Case is worth mentioning:

[... ] it becomes evident that in the relations between Turkey and the EU the standstill provisions of the Ankara Agreement, its Protocol and A ssociation Council Decision $1 / 80$ have retained all their topicality and importance. Where immigration was not restricted in a $\mathrm{M}$ ember State on the basis of language tests it cannot subsequently be restricted if it hinders economic freedom - unless it can be defended that the same provisions should be introduced on EU nationals; and this is a proposition that does not sit well with the project of 'ever closer Union'. Whereas enabling clauses such as the one contained in the Directive may lead to a downward trend in the protection of migrants, the Ankara A greement would protect against such a development. Such references by national courts are a golden opportunity for the Court of Justice to reaffirm the purpose of the Agreement and the Association Council Decision.

The European Court of Justice will also be able to carefully point out that $M$ ember States in all cases are required to respect human rights. In this regard, it is well possible that third country nationals are better protected under the family reunification directive and the A nkara A greement than they are under the European Convention of Human Rights. However, that circumstance does need not be elaborated upon here, and it was not among the questions asked. (pp. 31-32)

All in all, the visa requirement and other similar obstacles are still implemented by most of the member states. In an effort to revise the Customs Union, these problems breaching the freedom of movement should also be taken into consideration.

Transport quota

The last issue that should be mentioned is the quota applied to the goods, which are transported via road transport. The quotas that are slowly converted to the Turkish transport companies, and the visa requirement for truck drivers represent an obstacle to the free movement of goods and are contrary to the Customs U nion. The illegality of the visa regulations on lorry drivers has been confirmed by the ECJ in the Soysal Case, as has been discussed previously.

In accordance with A rticle 5 and 6 of Decision No 1/95 of the A ssociation Council customs tariffs, quantitative restrictions and measures with similar 
effect are prohibited. These items are the same as A rticles 28 and 29 of the Treaty Establishing the Community. A ccordingly, the interpretation of the $\mathrm{ECJ}$ judgment serves as a guide in this area. For example, in the Geddo Case (Case 2/73) all measures that limit all or part of the import, export or transit of the goods are defined as measures equivalent to the quantitative restrictions. The Dassonville Case clearly puts it:

All trading rules enacted by Member States which are capable of hindering, directly or indirectly, actually or potentially, intra-Community trade are to be considered as measures having an effect equivalent to quantitative restrictions (Case 8/74).

Later in the SIOT Decision (Case 266/81) which is directly related to the transportation issue, ECJ has laid down that:

Customs Union covers the free movement of goods in all conditions. This freedom cannot be exercised fully if the transit of goods is restricted or if there is a threat of restriction in any form [... ] This reveals that it cannot be charged any transit tax or raise any difficulty to the goods transit passing from a member state (p. 731).

The quotas that are applied to the Turkish transportation sector appear as measures with similar effect as customs duties and quota restrictions. The problem is that quotas have not been redefined in parallel with the increasing trade volume between Turkey and the EU. For example, Turkish exports grew by 1.86 times between 2002 and 2006, while the quotas were increased by only $50 \%$. In the same period, exports to Greece increased $41 \%$ whilst there has been no increase in the number of certificates. In any case, the consequence of the application of transport quotas to Turkish transportation is that it constitutes a 'non-tariff barrier' in the trade between Turkey and the EU, which is also in contradiction with the competition policy of the EU. As the report of the W orld B ank stated (2014):

EU transit permits for Turkish road transport operators raise trade costs. When carrying goods in the EU by road, Turkish operators must transit either Greece or Bulgaria. In Greece, there have been occasional problems with bilateral quotas although there are no reported problems with transit quotas. Greece exchanges 35,000 transit permits every year with Turkey, with a fee of $€ 100 /$ round trip. In Bulgaria, the main constraint is the fixed number of transit permits. For Bulgaria, Turkish road transport operators receive 250,000 transit permits per year at a cost of $€ 86 /$ round trip. In A ustria, Turkish carriers are obliged to use R O-LA (truck-on-train) transport due to the scarcity of permits exchanged with Austria on the grounds of environmental protection. Turkish road 
transport operators transit A ustria 130,000 times per year, mainly to reach Germany which is the destination of 70 percent of Turkish carriers, but receive just 15,000 permits so the remaining transits take place by RO-LA at an additional cost of $€ 250 /$ truck/transit. The RO-LA also creates large waiting times (4-5 days) waiting for transit documents. The journey normally takes 4 days so transport times are effectively doubled which is problematic especially for shipments of perishable goods. From Hungary, Turkish carriers receive 24,000 permits free of charge and 16,400 paid ( $€ 500 /$ round trip transit) for which the latter are unlimited. In Italy, the quota system is restrictive. Approximately, 100,000 Turkish trucks transit Italy every year, of which 70 percent go north and 30 percent travel west. Turkish trucks face no restrictions when they take the RO-RO to Trieste and then continue north, for example to Germany, but do require a permit if they travel west. Turkish road transport operators receive just 6,000 permits per year and are not allowed to buy additional ones. If they do not have a permit then they cannot transit Italy on an east-west basis. Italy requests a permit for empty trucks, as does Turkey. In Italy, the delays related to permits alone cost Turkish carriers $€ 250$ per truck per day [... ] For Romania, in case the free quota gets exhausted, Turkey is allowed to purchase as many transit permits as needed for $€ 1,200 /$ round trip. Some transit quotas for some countries are free if the journey time is less than 36 hours. However, in several EU member states when permits are exhausted, trade carried by Turkish road transport operators is effectively closed. (p. 54)

All in all, free trade agreements with third countries, the visa requirement for Turkish nationals and the quota imposed on the Turkish transportation sector are among the most serious problems that the Customs U nion burdens Turkey's interests.

\section{Conclusion}

The establishment of a customs union between Turkey and the EU is not the final goal of the association relationship that has been built with the A nkara A greement. The four fundamental freedoms (free movement of goods, persons, services and capital), which are enshrined in the Treaty establishing the Community, are also included in the Ankara A greement. However, the free movement of goods is the only freedom that has been completed so far. Even this area of freedom could not entirely be accomplished because of the main problems discussed previously.

Regarding the issues concerning the Customs Union, Turkey has only advisory capabilities and has no role in the decision-making process. Turkey is 
one of few countries that have a Customs Union with the EU whilst not being a member state. Therefore, the revision of institutional problems is necessary to promote further deepening of the Customs Union in line with the interests of the parties.

Initially, the visa practice for Turkish nationals -primarily businessmen- is in contradiction with the rules of competition. Therefore, elimination of the visa requirement for persons entering into $\mathrm{EU}$ territory for business purposes should be prioritized in order to alleviate the concerns of Turkey.

Moreover, the free trade agreements between the EU and third countries have proliferated in recent years. This development may have burdening effects on the Turkish economy. The negative expectations are based on the fact that Turkey could not be included in the trade negotiations between the EU and third countries. B ecause Turkey is a not a member state of the EU an additional FTA between Turkey and that third country could offset the negative impact of EU's new trade agreement. However, within the current structure of the Customs Union, there is no regular mechanism that enforces third parties to conclude an additional trade agreement with Turkey.

The lack of a new agreement between Turkey and a third country or trade bloc would lead to a competitive advantage for the latter. In more concrete terms, when a third country signs a FTA with the EU, that country will be able to sell its products in the Turkish market exempt from customs duties and quota restrictions. On the other hand, without the existence of any additional FTA with Turkey, Turkish products will not have free access to the internal market of the respective third country. This trade impact may be greater when the concerned third party is a significant trade actor in the world economy. TTIP, therefore, would have a considerably negative impact on Turkish economy if A merican producers enjoy the exemptions while their T urkish counterparts face customs duties and quota restrictions.

A nother disputed issue with regard to EU-Turkey relations is the restriction on the transit of Turkish vehicles. It is absolutely clear that this issue constitutes a breach of free movement, which contradicts the idea of a single market. Since Turkey's primary target is to be a part of the single market and the EU, such impediments would serve nothing more than distancing Turkey from the European markets and the integration process.

Turkey's Customs Union with the EU has been in practice for almost 20 years. The problems that were posed by the Customs Union on Turkey have grown in time and solutions were always postponed. This has partly resulted 
from the primary goal of Turkey, which is to be a member of the EU in a properly scheduled timeline. It is almost clear today that the accession negotiations with Turkey would take longer than expected. Opening of all negotiation chapters would help put EU-Turkey relations on track. This process would also be supported by the revision of the Customs Union, which will increase the support of the EU process in Turkey. The need for a revision of the Customs U nion was not solely asked for by Turkey. A W orld B ank report dated $M$ arch 2014 recognized the need for a revision and argued that an expansion of the Customs Union to some new sectors such as agriculture, services, and public procurement is necessary.

Finally, it should not be disregarded that EU-Turkey relations are not only based on economic and political dimensions, but have a social dimension as well. The open-ended structure of Turkey's membership, which would be subject to referendum in any member state, raises doubts in Turkey. A recent survey conducted in M armara University (Istanbul) depicts that the demarcation between Turkish identity and European values is increasing in Turkey. Göral et al. (2014) argue that Turkey's accession is the basis of cultural richness and diversity for the EU, which needs to be a global actor in the changing international system. Without Turkey's contribution it would be very difficult to justify a sincere idea based on European motto 'united in diversity'. 


\section{References:}

A greement Establishing an Association between the European Economic Community and Turkey and the A dditional Protocol (1973) Official Journal of the European Communities. Vol. 16, No. C113, December 24, $<\mathrm{http}$ //ec.europa.eu/enlargement/pdf/turkey/association_agreement_1964_e n.pdf $>$.

A kses, S. (2010) "İKV Değerlendirme Notu: AB-Güney Kore Serbest Ticaret A nlaşması ve Türkiye'deki Etkisi", <http://ikv.org.tr/images/upload/data /files/ikv_degerlendirme_notu_-_ab-guney_kore_serbest_ticaret_anlasmasi_ veturkiyēekeki_etkisi.pdf $>$.

Case 2/73 Riseria Luigi Geddo v Ente Nazionale Risi, <http://eurlex.europa.eu/legal-content/EN/TXT/?uri=CELEX :61973CJ 0002>.

Case 8/74 Procureur du Roi v Benoît and Gustave Dassonville, <http://curia. europa.eu/juris/showPdf.jsf?text $=\&$ docid $=88839 \&$ pagel ndex $=0 \&$ doclang $=E$ $N \&$ mode $=$ req $\&$ dir $=\&$ occ $=$ first $\&$ part $=1 \&$ cid $=91015>$.

Case 266/81. Società Italiana per I'Oleodotto Transalpino (SIOT) v M inistero delle finanze, $M$ inistero della marina mercantile, Circoscrizione doganale di Trieste and Ente autonomo del porto di Trieste. Retrieved from http://eurlex.europa.eu/legal-content/EN/TX T/?uri=CELEX:61981CJ 0266

Case C-12/86 Meryem Demirel $v$ Stadt Schwäbisch Gmünd, $<$ http://curia.europa.eu/juris/liste.jsf?language $=e n \&$ jur $=C, T, F \&$ num $=C$ $12 / 86 \& \mathrm{td}=\mathrm{A} L \mathrm{~L}>$.

Case C-92/07 European Commission $v$ Kingdom of the Netherlands, $<$ <ttp://curia.europa.eu/juris/liste.jsf?language=en $\&$ num $=C-92 / 07>$.

Case C-138/13 Naime Dogan v Bundesrepublik Deutschland, $<$ <ttp://curia.europa.eu/juris/liste.jsf?num=C-138/13>.

Case C-228/06 Mehmet Soysal v Ibrahim Savatli v Bundesrepublik Deutschland, <http://curia.europa.eu/juris/liste.jsf?language $=e n \&$ num $=C$ 228/06>.

Case C-513/12 Aslihan Nazli Ayalti v Federal Republic of Germany, $<$ <ttp://curia.europa.eu/juris/liste.jsf?language=en\& num =C-513/12>.

Court of J ustice of the European U nion (2014) Press Release No 96/14, July 10 L uxembourg: Court of J ustice of the European Union Press and Information, $<$ http://curia.europa.eu/jcms/upload/docs/application/pdf/2014-07/cp140096 en.pdf $>$. 
Dartan, M . (2002) Turkey-EU relations with particular reference to the customs union, in M. Dartan and C. Nas (eds.), The EU enlargement process and Turkey, (Istanbul: M armara University Publications), pp: 271-322.

Dartan, M. (2010) "Die B eziehungen der Türkei zur Europäischen Union", in M. Dartan, H. Lichtenberg and A. Eliş (eds.), Deutsch-Türkische Verhältnisse im europäischen Kontext, (Istanbul: Marmara Universität Publikations), pp: 103-133.

Decision No 1/95 of the EC-Turkey A ssociation Council of 22 December 1995 on implementing the final phase of the Customs U nion, 96/142/EC (1996). Official Journal of the European Communities. Vol. 39, L 35, <http://trade.ec.europa.eu/doclib/docs/2003/december/tradoc_115267.pdf>.

European Commission (2012) Commission Recommendation amending the recommendation establishing a common "Practical Handbook for Border Guards (Schengen Handbook)" to be used by Member States' competent authorities when carrying out the border control of persons (C (2006) 5186 final), December 14, <http://ec.europa.eu/dgs/home-affairs/elibrary/documents/policies/borders-and-visas/schengen/docs/commission_ recommendation_c_2012_9330_en.pdf>.

European Commission (2015) Trade: Countries and Regions: U nited States, October 29, <http://ec.europa.eu/trade/policy/countries-andregions/countries/united-states/>.

European Council (2004) Presidency Conclusions. Brussels: Council of the European Union, December 16/17, $<h$ ttp://data.consilium.europa.eu/doc/document/ST-16238-2004IN IT/en/pdf >.

Ferbelmayr, G. J. and Larch, M . (2013) The Transatlantic Trade and Investment Partnership (TTIP): Potentials, Problems and Perspectives, CESifo Forum, 14(2): 49-60.

Filippin, M. \& Neuwahl, N. (2014) Case c-138/13, Naime Dogan v. Bundesrepublik Deutschland. Marmara Journal of European Studies, 22(2), 123-126.

Göral, E., Özdemir, L., Y urtkoru, S. Y ., and Dartan, M . (2014) The perception of university students towards the European Union: An evaluation of Marmara University surveys conducted in 2004 and 2014. (Istanbul: M armara U niversity Publications).

Groenendijk, K., and Guild, E. (2010) Visa policy of Member States and the EU Towards Turkish Nationals After Soysal, (Istanbul: Economic Development Foundation Publications). 
Hallstein, W. (1963) Adress by Prof. Dr. Walter Hallstein, President of the Commission of the European Economic Community, on the occasion of the signature of the A ssociation A greement with Turkey, A nkara, 12 September 1963, <http://aei.pitt.edu/14311/1/S77.pdf>.

Kabaalioglu, H. (2012) "Turkey's R elations with the European U nion: Customs Union and Accession Negotiations", in P. C. Müller-Graff and $\mathrm{H}$. Kabaalioglu (eds.), Turkey and the European Union, (Baden Baden: Nomos), pp: 11-23.

Karakeçili, F. (2010) "Die Türkei-EU Zollunion und Einige H auptprobleme bei ihrer Umsetzung", in M. Dartan, H. Lichtenberg and A. Eliş (eds.), D eutschTürkische Verhältnisse im europäischen Kontext, (Istanbul: Marmara Universität Publikations), pp: 135-167.

Karluk, R. (1997) Gümrük Birliği Dönemecinde Türkiye. (A nkara: Turhan Kitabevi).

Kirişci, K., and Ekim, S. (2015) Why an EU -Turkey Customs U nion U pgrade is Good for Turkey. Washington, DC: The German Marshall Fund, $<$ http://ww w.gmfus.org/publications/why-eu-turkey-customs-unionupgrade-good-turkey>.

Neuwahl, N. (2013) "'No German, no love': Language proficiency as a condition for visas of Turkish spouses under EU law", Marmara Journal of European Studies, 21(2): 1-36.

Ortak Pazara Girdik. (1963) C umhuriyet, September 13.

Özen, Ç. (2002) Türkiye-Avrupa Topluluğu Gümrük Birliği ve Tam Üyelik Süreci Üzerine Etkileri, (İzmir: Ceylan Kitabevi).

Stevens, P. (2015) Time to talk Turkey on trade, April 15, $<$ http://thehill.com/blogs/congress-blog/foreign-policy/238785-time-to-talkturkey-on-trade>.

Taşdemir, İ. (2008) AB ve diğer uluslararası birlikler ile ilişkilerde Türkiye'nin seçenekleri. İstanbul Ticaret Odast, <http://www.ito.org.tr/itoyayin/0019090.pdf>.

World Bank (2014) Evaluation of the EU-Turkey Customs Union, <http://www.worldbank.org/content/dam/W orldbank/document/eca/turkey/t r-eu-customs-union-eng.pdf $>$.

Yilmaz, K. (2015) TTIP and EU-Turkish Economic Relations: Deepening the Customs Union. (Istanbul Policy Center Policy Brief 21) $<$ http://ipc.sabanciuniv.edu/en/publication/ttip-and-eu-turkish-economicrelations-deepening-the-customs-union/>. 
